\title{
Biology at the Imperial Social Hygiene Congress
}

\begin{abstract}
$\mathrm{T}$ the recent Congress held under the auspices of the British Social Hygiene Council at the London School of Hygiene and Tropical Medicine, the teaching of biology formed the main topic of the papers read during the educational sessions. It is satisfactory to hear from Dr. E. W. Shann that it is now realised that there are two categories of pupils to be considered in the drafting of syllabuses, namely, those for whom biology is a necessary part of their general education, and those who require it for vocational reasons. Up to an early stage, the needs of these two may be regarded as identical; and they will probably be met by a well-balanced course of general elementary science in which hygiene and the functions of the chief organs of the human body should certainly be included. The scheme advocated by Mrs. E. J. Hatfield, which is already in use in many girls' schools, and deserves the attention of others where the ages of pupils permit is: Age 11-12 years, general elementary science; age 12-14 years, chemistry, or chemistry and physics ; age 14-16 years, general biology, and in addition, chemistry or physics for future science specialists.

For purposes of general education, biology is unquestionably preferable to either zoology or botany; and that this is becoming more widely recognised by teachers is shown by the steady increase in the number of candidates offering biology at certificate examinations, and the corresponding diminution in that of those offering either of the other subjects. A knowledge of the structure and life-histories of a few typical animals and plants does not bestow on its possessor a biological outlook on the world around him and on the problems of mankind: the type system is dead so far as general education is concerned. It is biological topics rather than types that will eventually produce a biologically minded public, and, it is to be hoped, lead to social legislative measures based on the conviction that man is subject to the same laws of Nature as are all other animals.
\end{abstract}

The topics that are essential in such a course are (1) food elaboration by green plants, the source of all vital energy and conversions of energy; here is abundant opportunity for personal experimental work, even on the large scale, in rural schools possessing gardens ; (2) the structure of a mammal, and the functions of the chief organs ; (3) reproduction, asexual and sexual, in plants and animals; parental care, and its importance in evolution; (4) the web of life, and mutual interdependence; heredity ; evolution; biology in the service of man ; (5) bacteria and fungi, and their rôle in the nitrogenand carbon-cycles.

It is obvious that mammalian physiology will be human; nor is any apology for this necessary. A child is naturally and properly curious about the workings of its own body, and most children are keenly interested in living animals, and perhaps also in growing plants. Thus it becomes easy and not inappropriate to digress from the processes going on in the body of the living child to the methods by which the same processes are effected in other animals and in plants. For example, human respiration may well be followed by the methods of respiration found in, say, fish, snails and insects, and by demonstration of the fact that in plants respiration is essentially the same as in animals. Similar digressions can be made in connexion with all the other metabolic processes, which need not here be specified. In such a course, instruction on the details of structure would be reduced to the barest minimum ; morphology is for the specialist, not for the general public ; and the topies would be purely biological, and freed from the type incubus.

It is generally conceded that biological teaching is the best method of instructing in the laws of health and in the meaning of sex. Indeed, in some quarters sex-instruction has been the chief reason for advocating the inclusion of biology in all school curricula. Certainly knowledge of the sexual processes in plants and in the lower animals affords an avenue by which approach may be made to the relation of male and female in the human species; but to stress this aspect in a course of general biology is a mistake ; the functions of the reproductive system should have neither more nor less attention devoted to them than is given to those of the digestive, respiratory, excretory and the rest.

What matters most is that for all the processes of life there should be instilled a respect, a reverence for the mystery of life, an appreciation of the beauty of the form of living things and of their marvellous adaptations to their environment. Knowledge without the spirit of reverence will not have much influence on the moral conduct of man or of woman.

It is, then, very desirable that training colleges should emphasise this aspect of biology, and should insist on this subject being included in the science course; for the lack of qualified teachers has not yet been made good.

\section{The Museums Association}

\section{Annual Conference at Brussels}

$\mathrm{T}$ HE Museums Association, which has its headquarters in London, and holds its annual conference at different provincial centres in turn, this year departed from its usual custom, and, at the invitation of the Belgian Government, held its Con- ference in Brussels, where more than two hundred members assembled.

After the Sunday had been spent in visiting the city and its museums, formal proceedings began on Monday, July 1, when members were officially 
welcomed by the Belgian Minister of Education. Sir Eric Maclagan, director of the Victoria and Albert Museum, then gave his presidential address on "The Future of Museums". The increasing tendency in Great Britain for private collections to become absorbed into the public museums of the country, and the continued growth of the latter, has created, he said, a very serious problem, since ultimately the limit is reached beyond which expansion is practically impossible. Those in charge of museums must therefore become more and more selective in the choice of material. The principle whereby the contents of a museum are divided into public col. lections, exhibited with great care, and study collections available to students, is an ideal one, but it is practically impossible to adapt existing buildings to such a purpose. Another method of limitation, which could be applied to smaller museums, is that of specialisation, whereby individual museums would carry some groups of exhibits as near completion as possible. Museum federations offer opportunities to promote this by means of exchanges.

Above all, Sir Eric said, those in charge of museums should look forward and regulate their own activities with a view to those of their successors. If anything is to emerge unscathed from our troubled times, museums have a higher 'survival value' than almost any other contemporary institution.

The address was followed by a paper from Prof. Jean Capart, conservateur en chef of the Musées Royaux d'Art et d'Histoire, on "The Museum Spirit", which is, he said, to restore the voice to the dead. The scientific aspect of museum work is only a beginning; truth must not remain the personal benefit of the scholar, but must be widely distributed.

In the afternoon there were organised tours of the various departments of the Royal Museums of Art and History in Brussels, where in the evening a reception was held.

On the following day, Prof. F. Demanet, of the Musee Royal d'Histoire Naturelle, opened a discussion on "What is the best way of forming a palæontological collection?" The answer is, he believes, by means of regional investigations carried out by specialists, who would note every fact throwing light on the stratigraphy, palæobiology and ecology of the specimens collected. The collection of specimens should, in fact, become a science of observation. After this subject had been discussed by Drs. D. A. Allan and J. W. Jackson, of the Liverpool and Manchester Museums respectively, Dr. W. T. Calman, of the British Museum (Natural History), gave an illuminating account of the planning of the new Whale Room at that Museum, and Mr. K. de B. Codrington rounded off the morning by a scholarly and witty paper on "The Making of Museums".

The afternoon was kept free for visits to the Museums of Fine Arts and of Natural History (the latter remarkable for its fossil vertebrates), and in the evening members were the guests of Burgomaster Max at the Hotel de Ville.

On Wednesday, July 3, the Museums Association was privileged to attend the centenary celebrations of the Musées Royaux d'Art et d'Histoire, at which Their Majesties the King and Queen of the Belgians were present. After lunch, a visit to the Congo Museum at Tervueren showed how admirably a single Museum could cover all aspects of the Belgian Congo-its history, natural history, economic resources, ethnography and art-and also provided an enjoyable excursion through the Forêt des Soignes. The annual dinner was held in the evening.

The meetings on Thursday, July 4, took place at the International Exhibition at Brussels. After Mr. P. Dikaios had given an account of the reorganisation of the archæological museum at Nicosia, Cyprus, and Dr. H. J. Plenderleith, of the British Museum, had discussed the application of scientific research to the study of works of art-in which he pointed out that the scientific specialist needs a knowledge of painting if he would avoid errors when working in this field--visits were paid to the magnificent collection of "Art Ancien" and to the other attractions, scientific, artistic and popular, of the Brussels Exhibition.

Friday and Saturday mornings were devoted to excursions to Antwerp, with its unique Museum of Printing, the Musée Plantin-Moretus, and to Bruges, where the effective design of the new municipal museum was greatly admired.

During the Conference, meetings were very well attended, in spite of the many counter-attractions of Brussels, of its museums, and of the Exhibition, and at the end of the week those who took part returned to England agreed that the decision to meet abroad had been fully justified by the success of the meeting.

The next annual conference of the Association will be held at the Leeds City Museum and Art Gallery, in July, 1936.

\section{Educational Topics and Events}

BELFAST.-At the graduation ceremony on July 10, honorary degrees were conferred upon, among others, Prof. T. G. Moorhead, regius professor of physic, Trinity College, Dublin; Dr. T. Carnwath, senior medical officer, Ministry of Health; Major-General W. P. Macarthur, Deputy Director-General, Army Medical Services; and the degree of D.Sc. was conferred on J. B. Parke for work on the viscosity of emulsions.

Dublin.-On July 5 the University of Dublin conferred the following honorary degrees: D.Sc.Prof. G. T. Morgan, director of the Chemical Research Laboratory at Teddington. Litt.D.-Sir Frederic Kenyon, formerly director of the British Museum. M.D.-Prof. T. H. Milroy, professor of physiology in Queen's University, Belfast, and Sir Norman Walker, direct representative for Scotland on the General Medical Council.

Lrverpool.-At a meeting of the Council on July 9, Mr. Thomas Bertrand Abell, professor of naval architecture and dean of the Faculty of Engineering, was appointed pro-vice-chancellor of the University for the session 1935-36. Prof. Abell, who has occupied the chair of naval architecture since 1914, had a distinguished career at the Royal Naval College, Devonport, and has held various appointments under the Admiralty, at the Royal Naval College, Greenwich, and the Royal Naval War College, Portsmouth. During the War he was assistant director of designs to the Admiralty and Ministry of Shipping and was awarded the O.B.E. for his War services.

The Council has also appointed Mr. J. F. Craig to the William Prescott chair of the care of animals as from October next. Mr. Craig has been on the staff of the Veterinary College of Ireland since 1903, having succeeded to the position of principal in 1918 . 